\title{
Analisis Pelaksanaan Kurikulum Pembelajaran Pada SMAKON Aceh Tahun Pengajaran 2020/2021
}

\author{
Hendry Fadly ${ }^{1}$, Haris Munandar ${ }^{2}$ \\ ${ }^{1}$ Dosen Fakultas Keguruan dan Ilmu Pendidikan Universitas Serambi Mekkah \\ ${ }^{2}$ Alumni Fakultas Keguruan dan Ilmu Pendidikan Universitas Serambi Mekkah \\ hendrifadly1991@gmail.com
}

\begin{abstract}
Abstrak
Penelitian yang berjudul. "Analisis Pelaksanaan Kurikulum Pembelajaran Pada SMAKON Aceh Tahun Pengajaran 2020/2021". Rumusan masalah yang diteliti adalah Analisis Pelaksanaan Kurikulum Pembelajaran Pada SMAKON Aceh Tahun Pengajaran 2020/2021. Pertanyaan penelitian adalah Bagaimana Pelaksanaan Analisis Pelaksanaan Kurikulum Pembelajaran Pada SMAKON Aceh Tahun Pengajaran 2020/2021. Tujuan penelitian adalah untuk melihat sejauh mana pelaksaan Kurikulum Pembelajaran Pada SMAKON Aceh Tahun Pengajaran 2020/2021. Penelitian yang digunakan untuk penelitian ini adalah kualitatif. Sampel dalam penelitian ini adalah Guru SMAKON sebanyak 3 orang. Semua populasi dijadikan sebagai sampel penelitian. Metode pengumpulan data yang digunakan dalam penelitian ini adalah metode triangulasi atau penggabungan, yaitu observasi, wawancara, dan dokumentasi. Teknik analisis data yaitu (1) Reduksi Data, (2) Display Data, dan (3) Mengambil kesimpulan serta verifikasi Dari hasil wawancara peneliti kepada ke tiga subjek dapat diketahui bahwa secara keseluruhan hasil penelitian Analisis Pelaksanaan Kurikulum Pembelajaran Pada SMAKON Aceh Tahun Pengajaran 2020/2021 sudah berjalan dengan baik, terlihat berdasarkan indikator penerapan kurikulum, penerapan K13 sudah dilaksanakan oleh guru PJOK SMKON Aceh dengan baik, guru PJOK SMAKON sudah memahami K13 dengan baik, pelaksanaan K13 di SMAKON Aceh juga dilaksanakan sesuai dengan kurukulum, adapun kesulitan yang di alami dapat terselesaikan dengan baik, kekurangan yang didapat oleh guru PJOK SMKON Aceh dapat di selesaikan dengan baik, contohnya kurang sarana dan prasarana, sehingga dapat dinyatakan bahwa pelaksanaan, penerapan dan kesulitan kurikulum 2013 khususnya untuk mata pelajaran pendidikan jasmani, olahraga, dan kesehatan di Sekolah SMKON Aceh berjalan dengan baik.
\end{abstract}

\section{Kata kunci : Analisis Pelaksanaan Kurikulum Pembelajaran}

\section{PENDAHULUAN}

Pendidikan merupakan penentuan maju dan mundurnya suatu bangsa. Sebab pendidikan merupakan sarana penunjang untuk menuju pertumbuhan, perkembangan dan kemajuan suatu bangsa. Hal ini dapat terlihat dari tujuan pendidikan yang tercantum dalam Undang-undang No. 20 tahun 2003 tentang Sistem Pendidikan Nasional Bab II pasal 3, yang berbunyi sebagai berikut, "Pendidikan nasional berfungsi mengembangkan kemampuan dan membentuk watak serta peradaban bangsa yang bermartabat dalam rangka mencerdaskan kehidupan bangsa, bertujuan untuk berkembangnya potensi peserta didik agar menjadi manusia yang beriman dan bertakwa kepada Tuhan Yang Maha Esa, berakhlak mulia, sehat, berilmu, cakap, kreatif, mandiri, dan menjadi warga negara yang demokratis serta bertanggung jawab". Pentingnya pendidikan tidak dapat dipungkiri oleh siapa pun. 
Pendidikan berhasil mengembangkan segala potensi yang dimiliki oleh individu yang secara alami sudah dia miliki. Potensi yang dimiliki oleh individu tersebut apabila tidak dikembangkan menjadi sumber daya yang terpendam tanpa dapat kita lihat dan rasakan hasilnya, untuk itu individu perlu diberi berbagai kreatifitas, tanggung jawab keterampilan. Upaya peningkatan mutu pendidikan yang dilakukan sekarang ini adalah penggantian kurikulum pendidikan yang diterapkan pada sekolah-sekolah. Kurikulum merupakan seperangkat rencana dan pengaturan pendidikan dan hasil pendidikan. Perubahan kurikulum tidak lepas dari upaya pemerintah untuk menemukan suatu kurikulum yang cocok dan sesuai sehingga terwujudnya pelaksanaan pembelajaran yang efektif dan berkualitas bagi guru dan siswa dapat mengikutinya dengan baik sehingga hasil akhir dari pendidikan adalah menciptaakan generasi muda bangsa yang berkualitas dan memiliki kompetensi di bidangnya.

Penyusunan perangkat mata pelajaran ini disesuaikan dengan keadaan kemampuan setiap jenjang pendidikan dalam penyelenggaraan pendidikan tersebut. Lama waktu dalam satu kurikulum biasanya disesuaikan dengan maksud dan tujuan dari sistem pendidikan yang dilaksanakan. Kurikulum ini dimaksudkan untuk dapat mengarahkan pendidikan menuju arah dan tujuan yang dimaksudkan dalam kegiatan pembelajaran secara menyeluruh. Kurikulum 2013 sering disebut juga dengan kurikulum berbasis karakter. Kurikulum ini merupakan kurikulum baru yang dikeluarkan oleh Kementerian Pendidikan dan Kebudayaan Republik Indonesia.

Pelajaran yang perlu pengaplikasian atau peraktek sangat penting yaitu pelajaran Pendidikan Jasmani Olahraga dan Kesehatan (PJOK). Pendidikan jasmani olahraga dan kesehatan yang merupakan bagian yang tak terpisahkan dari pendidikan yang tentu di dalamnya ada proses pembelajaran. Apabila dibandingkan dengan proses pembelajaran mata pelajaran lainnya, proses pembelajaran pendidikan jasmani sangatlah berbeda. Pendidikan jasmani olahraga dan kesehatan mengajak siswa untuk dapat berkembang sesuai dengan keinginannya.

Peraturan Menteri Pendidikan Nasional Republik Indonesia nomor 22 tentang Standar Kompetensi Lulusan (SKL) untuk satuan pendidikan dasar dan menengah bahwa:

Pendidikan jasmani olahraga dan kesehatan merupakan bagian integral dari pendidikan secara keseluruhan, bertujuan untuk mengembangkan aspek kebugaran jasmani, keterampilan gerak, keterampilan erfikir kritis, keterampilan sosial, penalaran, stabilitas emosional, tindakan moral, aspek pola hidup sehat dan pengenalan lingkungan bersih melalui aktivitas jasmani, terpilih yang direncanakan secara sistematis dalam rangka mencapai tujuan pendidikan nasional.

Untuk mencapai hasil belajar yang maksimal pembelajaran PJOK yang disajikan oleh para guru haruslah berdasarkan panduan atau tuntunan belajar yang dilandaskan pada Silabus. Silabus adalah rencana pembelajaran pada suatu kelompok mata pelajaran dengan tema tertentu yang mencakup standar kompetensi, kompetensi dasar, materi pembelajaran, indikator, penilaian, alokasi waktu, dan sumber belajar yang dikembangkan oleh setiap satuan pendidikan.

SMAKON pertama kali dibangun pada tanggal 4 mei 2017, dan mulai aktif melaksanakan proses belajar mengajar pada 15 Juli 2019, dengan tujuan SMAKON dapat mewakili aspirasi dan peran serta masyarakat sebagai bentuk kepudilian terhadap 
perkembangan dunia pendidikan dan untuk mendidik siswa agar tumbuh menjadi cerdas, bijaksana dan bermanfaat bagi bangsa dan negara.

Hasil observasi peneliti pada tanggal 25 Juni 2020 bahwa SMAKON Aceh telah menggunakan kurikulum 2013, selama menerapkan kurikulum 2013 SMAKON dapat menyesuaikan sistem pembelajaran dengan program latihan yang telah disiapkan, dengan kurikulum 2013 hasil yang diperoleh SMAKON seimbang, pembelajaran dapat berjalan dengan baik, latihan juga dapat terlaksanakan.

Berdasarkan uraian di atas sitem pembelajaran penjasorkes di SMAKON dengan menggunakan kurikulum 2013 peneliti ingin mengambil judul tentang "Analisis Pelaksanaan Kurikulum Pembelajaran Pada SMAKON Aceh Tahun Pengajaran 2020/2021".

\section{Tujuan Penelitian}

Berdasarkan rumusan masalah, maka tujuan penelitian adalah untuk melihat sejauh mana pelaksaan Kurikulum Pembelajaran Pada SMAKON Aceh Tahun Pengajaran 2020/2021.

\section{LANDASAN TEORITIS \\ Pelaksanaan Pembelajaran}

Pelaksanaan pembelajaran adalah proses yang diatursedemikian rupa menurut langkah-langkah tertentu agar pelaksanaan mencapai hasil yang diharapkan (Sudjana, 2010:136 ). Menurut Majid (2014:129), pelaksanaan pembelajaran merupakan kegiatan proses belajar-mengajar sebagai unsur inti dari aktivitas pembelajaran yang dalam pelaksanaannya disesuaikan dengan rambu-rambu yang telah di susun dalam perencanaan sebelumnya. Menurut Bahri dan Aswan Zain (2010:28) pelaksanaan pembelajaran adalah suatu kegiatan yang bernilai edukatif, nilai edukatif mewarnai interaksi yang terjadi antara guru dan peserta didik. Interaksi yang bernilai edukatif dikarenakan pelaksanaan pembelajaran yang dilakukan diarahkan untuk mencapai tujuan tertentu yang telah dirumuskan sebelum pelaksanaan pembelajaran dimulai.

\section{Kurikulum}

Kurikulum secara etimologis adalah tempat berlari dengan kata yang berasal dari bahasa Latin curir yaitu pelari, dan curere yang artinya tempat berlari. Dalam sejarahnya, kurikulum merupakan suatu jarak yang harus ditempuh pelari mulai dari garis awal sampai dengan finish, kemudian pengertian kurikulum tersebut juga mendapat tempat didunia pendidikan, dengan pengertian sebagai rencana dan pengaturan tentang sejumlah mata pelajaran yang harus dipelajari pesrta didik dalam menempuh pendidikan dilembaga pendidikan (Imas Kurinasih dan Berlin Sani, 2014:3) Peraturan Menteri Pendidikan dan Kebudayaan Nomor 69 tahun 2013 tentang Kerangka Dasar dan Struktur Kurikulum Sekolah Menengah Atas/Madrasah Aliyah. Undang-Undang Nomor 20 Tahun 2003 tentang Sistem Pendidikan Nasional menyebutkan bahwa kurikulum adalah seperangkat rencana dan pengaturan mengenai tujuan, isi, dan bahan pelajaran serta cara yang digunakan sebagai pedoman penyelenggaraan kegiatan pembelajaran untuk mencapai tujuan pendidikan tertentu.

Kurikulum 2013 dikembangkan berdasarkan faktor-faktor sebagai berikut:

1. Tantangan Internal

2. Tantangan Eksternal 


\section{METODOLOGI PENELITIAN Rancangan Penelitian}

Rancangan atau desian penelitian merupakan tahapan-tahapan penelitian yang dilakukan peneliti. Penelitian ini didesain dengan menggunakan metode Deskriptif Analisis dengan pendekatan Kualitatif. Pemilihan desain penelitian bertujuan untuk menjawab pertanyaan yang menjadi dasar penelitian, terutama masalah langkahlangkah pelaksanaan kurikulum 2013 yang difokuskan pada pembelajaran penjasorkes. Bidang penjasorkes dirasa tepat untuk dipilih karena sesuai dengan kompetensi peneliti yang berasal dari pendidikan olahraga USM.

\section{Waktu Dan Tempat Penelitian}

Penelitian ini akan di laksanakan di SMAKON Aceh Stadion Harapan bangsa pada bulan Oktober Tahun 2020.

\section{Populasi Dan Sampel}

Menurut Suharsimi Arikunto (2006: 130), populasi adalah keseluruhan subjek penelitian. Sedangkan Sugiyono (2006: 55) mendefinisikan populasi sebagai objek/subjek yang mempunyai kuantitas dan karakteristik yang ditetapkan oleh peneliti untuk dipelajari dan kemudian disimpulkan. Populasi dalam penelitian ini adalah Guru SMAKON sebanyak 3 orang. Semua populasi dijadikan sebagai sampel penelitian, sehingga dinamakan sebagai penelitian populasi. Jadi subjek penelitian yang digunakan dalam penelitian ini adalah 2 responden.

Sampel dalam penelitian ini adalah Guru SMAKON sebanyak 3 orang. Semua populasi dijadikan sebagai sampel penelitian, sehingga dinamakan sebagai penelitian populasi. Jadi subjek penelitian yang digunakan dalam penelitian ini adalah 3 responden.

Tabel Nama - Nama Guru Olahraga SMAKON Aceh

\begin{tabular}{|c|l|c|}
\hline No & \multicolumn{1}{|c|}{ Nama } & Jabatan \\
\hline 1 & Sufriadi, S.Pd. M.Pd & Plt. Kepala Sekolah \\
\hline 2 & Drs.Muhammad Mahlian & Wakil Kurikulum \\
\hline 3 & Taufiq S.Pd. M.Pd & Guru Olahraga \\
\hline
\end{tabular}

\section{Teknik Pengumpulan Data}

Teknik pengumpulan data merupakan langkah paling strategis dalam penelitian, karena tujuan utama dari penelitian adalah mendapatkan data. Tanpa mengetahui metode pengumpulan data, maka peneliti tidak akan mendapatkan data yang memenuhi standar data yang ditetapkan. (Sugiyono,2009:224). Metode pengumpulan data yang digunakan dalam penelitian ini adalah metode triangulasi atau penggabungan, yaitu observasi, wawancara, dan dokumentasi.

\section{Teknik Analisis Data}

Menurut Sugiyono (2010:334) menyatakan bahwa: "Melakukan analisis adalah pekerjaan yang sulit, memerlukan kerja keras. Analisis memerlukan daya kreatif serta kemampuan intektual yang tinggi. Tidak ada cara tertentu yang harus diikuti untuk mengadakan analisis, sehingga setiap peneliti harus mencari sendiri metode yang dirasakan cocok dengan sifat penelitiannya. Bahan yang sama bisa diklarifikasikan lain oleh peneliti yang berbeda".

Berdasarkan kutipan di atas dapat dijelaskan bahwa analisis data merupakan cara yang tidak mudah untuk dilakukan, diperlukan cara yang kreatif sehingga 
mendapatkan informasi yang telah disiapkan, sehingga hasilnya akan baik. Dan apa yang nantinya disimpulkan selain bisa dipahami oleh diri sendiri juga untuk orang lain nantinya.

Prosedur data yang dilakukan sesuai dengan yang dikemukakan oleh Nasution (2003:129) yaitu (1) Reduksi Data, (2) Display Data, dan (3) Mengambil kesimpulan serta verifikasi.

\section{HASIL DAN PEMBAHASAN PENELITIAN \\ Hasil Penelitian}

Pengolahan data hasil penelitian jawaban yang diberikan oleh responden terhadap pertanyaan-pertanyaan yang tertuang dalam wawancara tentang pelaksanaan kurikulum di Sekolah SMAKON Aceh.

Hasil penelitian membuktikan bahwa riset deskriptif yang bersifat eksploratif bertujuan untuk menggambarkan keadaan atau status fenomena (Arikunto, 1993:209). Hasil perhitungan yang diperoleh dari jawaban dan data yang terkumpul kemudian diklasifikasikan dengan menggunakan pendekatan kualitatif. Adapun data yang bersifat kualitatif yaitu data yang digambarkan dengan kata-kata atau kalimat.

Dalam penelitian ini subjek yang di wawancara berjumlah 3 orang. Hasil penelitian tentang pelaksanaan kurikulum di Sekolah SMAKON Aceh, adalah sebagai berikut:

\section{a. Hasil Wawancara dengan Plt Kepela Sekolah.}

1. Bagaimana pendapat Bapak/Ibu tentang penerapan Kurikulum K13 di sekolah Bapak/Ibu?

Jawab:

Sudah baik, terlihat setiap guru pjok di SMAKON Aceh telah membuat perangkat pembelajaran sesuai dengan kurikulim 2013, contoh nya ada silabus, RPP, Prota, dll.

2.Bagaimanakah pendapat Bapak/Ibu menggunakan Kurikulum K13, berdasarakan standar kelulusan dan standar isi?

Jawab:

Sudah sesuai karena dengan K13 kompetensi dasar dan tujuan-tujuan yang telah dirumuskan dapat dicapai oleh peserta didik melalui pembelajaran

3. Apakah Bapak/Ibu setuju guru pendidikan jasmani tidak melakukan proses belajar mengajar dengan kurikulum tersebut?

Jawab :

Tidak setuju, karena K13 dibuat sudah sesuai dengan pembelajaran di SMAKON Aceh

4. Bila masih ada guru yang melakukan proses belajar mengajar dengan kurikulum yang lama, kepala sekolah memberikan ketegasan kepada guru yang bersangkutan?

Jawab:

Iya, sudah pasti karena tidak menggunakan kurikulum yang diarahkan oleh Dinas Pendidikan Aceh

5. Apakah Bapak/Ibu bila sebagai guru pendidikan jasmani harus memahami konsep dasar pendidikan jasmani berdasarkan K13?

Jawab :

Sudah pasti, karena akan kesulitas guru PJOK mengajar apabila tidak memahami konsep dasar K13

6. Apabila dalam proses pembelajaran siswa tidak memahami tentang materi yang 
telah diberikan, maka Bapak/Ibu menjelaskan kembali?

Jawab :

Iya, apabila 1 metode peserta didik belum memahami materi yang di ajarkan, maka guru PJOK akan memberikan metode lain agar mudah di pahami oleh peserta didik

7. Apakah Bapak/Ibu setuju guru pendidikan jasmani memahami evaluasi pendidikan jasmani berdasarkan Kurikulum K13?

Jawab :

Iya harus karena Hasil evaluasi dapat digunakan untuk berbagai kepentingan, memberikan penilaian terhadap peserta didik.

8. Bapak/Ibu mengalami kesulitan dalam melakukan pelaksanaan Kurikulum K13? Jawab :

Tidak terlalu sulit karena materi dan bahan ajar sudah lengkap dan saran dan prasaran juga sudah mendukung.

9. Apakah sarana dan fasilitas di sekolah ini, telah mendukung penerapan Kurikulum K13?

Jawab :

Sudah, walaupun ada beberapah alat yang kurang tapi guru PJOK dapat mengatasinya.

10. Dalam menanggulangi kekurangan sarana dan prasarana Bapak/Ibu setuju memodifikasi sendiri pembelajaran PJOK tersebut dalam mendukung penerapan $\mathrm{K} 13$ ?

Jawab :

Setuju, karena dengan alat modifikasi tersebut pembelajaran kepada peserta didi dapat berjalan dengan baik.

\section{b. Hasil Wawancara dengan Wakil Kurikulum}

1. Bagaimana pendapat Bapak/Ibu tentang penerapan Kurikulum K13 di sekolah Bapak/Ibu?

Jawab:

Sudah berjalan dengan baik, Nampak dilapangan guru pjok di SMAKON Aceh telah membuat perangkat pembelajaran sesuai dengan kurikulim 2013, contoh nya ada silabus, RPP, Prose, Prota dan lainnya.

2. Bagaimanakah pendapat Bapak/Ibu menggunakan Kurikulum K13, berdasarakan standar kelulusan dan standar isi?

Jawab:

K13 sudah cocok menjadi standar kululusan, stndar isi kompetensi dasar dan tujuan-tujuan yang telah dirumuskan dapat dicapai oleh peserta didik melalui pembelajaran

3. Apakah Bapak/Ibu setuju guru pendidikan jasmani tidak melakukan proses belajar mengajar dengan kurikulum tersebut?

Jawab :

Tidak setuju, karena K13 dirancang sesuai dengan pembelajaran di SMAKON Aceh

4. Bila masih ada guru yang melakukan proses belajar mengajar dengan kurikulum yang lama, kepala sekolah memberikan ketegasan kepada guru yang bersangkutan?

Jawab:

Iya, sudah pasti karena tidak menggunakan kurikulum yang diarahkan oleh Dinas 
Pendidikan Aceh

5. Apakah Bapak/Ibu bila sebagai guru pendidikan jasmani harus memahami konsep dasar pendidikan jasmani berdasarkan K13?

Jawab :

Sudah seharusnya, karena akan kesulitas guru PJOK mengajar apabila tidak memahami konsep dasar K13

6. Apabila dalam proses pembelajaran siswa tidak memahami tentang materi yang telah diberikan, maka Bapak/Ibu menjelaskan kembali?

Jawab :

Iya, apabila 1 metode peserta didik belum memahami materi yang di ajarkan, maka guru PJOK akan memberikan metode lain agar mudah di pahami oleh peserta didik

7. Apakah Bapak/Ibu setuju guru pendidikan jasmani memahami evaluasi pendidikan jasmani berdasarkan Kurikulum K13?

Jawab :

Iya harus karena hasil evaluasi dapat digunakan untuk berbagai kepentingan, memberikan penilaian terhadap peserta didik

8. Bapak/Ibu mengalami kesulitan dalam melakukan pelaksanaan Kurikulum K13? Jawab :

Tidak terlalu sulit karena materi dan bahan ajar sudah lengkap dan saran dan prasaran juga sudah mendukung.

9. Apakah sarana dan fasilitas di sekolah ini, telah mendukung penerapan Kurikulum K13?

Jawab :

Sudah, walaupun ada beberapah alat yang kurang tapi guru PJOK dapat mengatasinya.

10. Dalam menanggulangi kekurangan sarana dan prasarana Bapak/Ibu setuju memodifikasi sendiri pembelajaran PJOK tersebut dalam mendukung penerapan $\mathrm{K} 13$ ?

Jawab :

Setuju, karena dengan alat modifikasi tersebut pembelajaran kepada peserta didi dapat berjalan dengan baik.

\section{c. Hasil Wawancara dengan Guru PJOK}

1. Bagaimana pendapat Bapak/Ibu tentang penerapan Kurikulum K13 di sekolah Bapak/Ibu?

Jawab:

Sudah berjalan dengan baik, Nampak dilapangan guru pjok di SMAKON Aceh telah membuat perangkat pembelajaran sesuai dengan kurikulim 2013, contoh nya ada silabus, RPP, Prose, Prota dan lainnya

2. Bagaimanakah pendapat Bapak/Ibu menggunakan Kurikulum K13, berdasarakan standar kelulusan dan standar isi?

Jawab:

K13 sudah cocok menjadi standar kululusan, stndar isi kompetensi dasar dan tujuan-tujuan yang telah dirumuskan dapat dicapai oleh peserta didik melalui pembelajaran

3. Apakah Bapak/Ibu setuju guru pendidikan jasmani tidak melakukan proses belajar mengajar dengan kurikulum tersebut? Jawab : 
Tidak setuju, karena K13 dirancang sesuai dengan pembelajaran di SMAKON Aceh

4. Bila masih ada guru yang melakukan proses belajar mengajar dengan kurikulum yang lama, kepala sekolah memberikan ketegasan kepada guru yang bersangkutan?

Jawab:

Iya, sudah pasti karena tidak menggunakan kurikulum yang diarahkan oleh Dinas Pendidikan Aceh

5. Apakah Bapak/Ibu bila sebagai guru pendidikan jasmani harus memahami konsep dasar pendidikan jasmani berdasarkan K13?

Jawab :

Sudah seharusnya, karena akan kesulitas guru PJOK mengajar apabila tidak memahami konsep dasar K13

6. Apabila dalam proses pembelajaran siswa tidak memahami tentang materi yang telah diberikan, maka Bapak/Ibu menjelaskan kembali? Jawab :

Iya, apabila 1 metode peserta didik belum memahami materi yang di ajarkan, maka guru PJOK akan memberikan metode lain agar mudah di pahami oleh peserta didik

7. Apakah Bapak/Ibu setuju guru pendidikan jasmani memahami evaluasi pendidikan jasmani berdasarkan Kurikulum K13?

Jawab :

Iya harus karena hasil evaluasi dapat digunakan untuk berbagai kepentingan, memberikan penilaian terhadap peserta didik.

8. Bapak/Ibu mengalami kesulitan dalam melakukan pelaksanaan Kurikulum K13? Jawab :

Tidak terlalu sulit karena materi dan bahan ajar sudah lengkap dan saran dan prasaran juga sudah mendukung.

9. Apakah sarana dan fasilitas di sekolah ini, telah mendukung penerapan Kurikulum K13?

Jawab :

Sudah, walaupun ada beberapah alat yang kurang tapi guru PJOK dapat mengatasinya

10. Dalam menanggulangi kekurangan sarana dan prasarana Bapak/Ibu setuju memodifikasi sendiri pembelajaran PJOK tersebut dalam mendukung penerapan $\mathrm{K} 13$ ?

Jawab : Setuju, karena dengan alat modifikasi tersebut pembelajaran kepada peserta didi dapat berjalan dengan baik.

\section{Pembahasan Penelitian}

Dari hasil wawancara peneliti kepada ke tiga subjek dapat diketahui bahwa secara keseluruhan hasil penelitian Analisis Pelaksanaan Kurikulum Pembelajaran Pada SMAKON Aceh Tahun Pengajaran 2020/2021 sudah berjalan dengan baik, terlihat berdasarkan indikator penerapan kurikulum, penerapan K13 sudah dilaksanakan oleh guru PJOK SMKON Aceh dengan baik, guru PJOK SMAKON sudah memahami K13 dengan baik, pelaksanaan K13 di SMAKON Aceh juga dilaksanakan sesuai dengan kurukulum, pemahaman konsep juga sudah baik, terlihat di SMKAN Aceh pelaksanaan K13 sesuai dengan konsep yang sudah dirumuskan, untuk penerapan 
materi K13 juga sudah baik, guru PJOK dengan baik materi - materi yang akan di sampaikan kepada peserta didik, adapun kesulitan yang di alami dapat terselesaikan dengan baik, kekurangan yang didapat oleh guru PJOK SMKON Aceh dapat di selesaikan dengan baik, contohnya kurang sarana dan prasarana, sehingga dapat dinyatakan bahwa pelaksanaan, penerapan dan kesulitan kurikulum 2013 khususnya untuk mata pelajaran pendidikan jasmani, olahraga, dan kesehatan di Sekolah SMKON Aceh berjalan dengan baik.

Kurikulum merupakan salah satu komponen pembelajaran yang mempunyai peranan penting dalam Kegiatan Belajar Mengajar. Kurikulum seharusnya merupakan bagian yang harus mendapat perhatian guru dalam setiap kegiatan pembelajaran. Oleh karena itu guru perlu mempelajari bagaimana menetapkan kurikulum agar dapat mengefektifkan pencapaian tujuan pembelajaran dalam proses belajar mengajar.

Menurut UU No. 20 Tahun 2003: Kurikulum adalah seperangkat rencana dan pengaturan mengenai tujuan, isi, dan bahan pelajaran serta cara yang digunakan sebagai pedoman penyelenggaraan kegiatan pembelajaran untuk mencapai tujuan pendidikan nasional.

Kurikulum 2013 merupakan perangkat mata pelajaran dan program pendidikan berbasia sains yang diberikan oleh suatu lembaga penyelenggara pendidikan dengan tujuan untuk mempersiapkan lahirnya generasi emas bangsa indonesia, dengan sistem dimana siswa lebih aktif dalam kegiatan belajar mengajar. Titik beratnya, kurikulum 2013 ini bertujuan untuk mendorong peserta didik atau siswa agar lebih baik dalam melakukan observasi, bertanya, bernalar, dan mempresentasikan apa yang mereka peroleh atau mereka ketahui setelah meneerima materi pembelajaran. Adapun obyek yang menjadi pembelajaran dalam penataan dan penyempurnaan kurikulum 2013 menekankan pada fenomena alam, sosial, seni, dan budaya. Berbeda dengan kurikulum sebelumnya, kurikulum 2013 lebih menekankan pada ketiga aspek, yaitu menghasilkan peserta didik berakhlak mulia (afektif), berketerampilan (psikomotorik), dan berpengetahuan (kognitif) yang berkesinambungan. Sehingga diharapkan agar siswa lebih kreatif, inovatif dan lebih produktif.

\section{Kesimpulan}

Berdasarkan hasil penelitian dan pembahasan dapat diambil kesimpulan bahwa pelaksanaan kurikulum pembelajaran pada Sekolah Menengah Keberbakatan Olahraga Nasional Aceh Tahun Pengajaran 2020/2021. Dari hasil wawancara peneliti kepada ke tiga subjek dapat diketahui bahwa secara keseluruhan hasil penelitian Analisis Pelaksanaan Kurikulum Pembelajaran Pada Sekolah Menengah Keberbakatan Olahraga Nasional Aceh Tahun Pengajaran 2020/2021 sudah berjalan dengan baik, terlihat berdasarkan indikator penerapan kurikulum, penerapan K13 sudah dilaksanakan oleh guru PJOK SMKON Aceh dengan baik, guru PJOK Sekolah Menengah Keberbakatan Olahraga Nasional Aceh sudah memahami K13 dengan baik, pelaksanaan K13 di Sekolah Menengah Keberbakatan Olahraga Nasional Aceh juga dilaksanakan sesuai dengan kurukulum, adapun kesulitan yang di alami dapat terselesaikan dengan baik, kekurangan yang didapat oleh guru PJOK SMKON Aceh dapat di selesaikan dengan baik, contohnya kurang sarana dan prasarana, guru PJOK dapat memodivikasi sarana dan prasarana sekolah, dengan demikian pelaksanaan penjas d SMKON Aceh dapat berjalan dengan baik, sehingga dapat dinyatakan bahwa pelaksanaan, penerapan dan kesulitan kurikulum 2013 khususnya untuk mata pelajaran pendidikan jasmani, olahraga, dan kesehatan di Sekolah SMKON Aceh berjalan dengan baik. 


\section{DAFTAR PUSTAKA}

Abdul Majid. (2014). Strategi Pembelajaran. Bandung: PT Remaja Rosdakarya.

Arikunto, S. 2006. Metode Penelitian Kualitatif. Jakarta: Bumi Aksara

Berlin sani, 2014. "Strategi Pembelajaran didalam Kelas". Alfabeta:Bandung

Depdiknas .2003. Undang-undang RI No.20 tahun 2003.tentang sistem pendidikan nasional.

Depdiknas .2006. Permendiknas No 22 Tahun 2006 Tentang Standar Isi. Jakarta : Depdiknas.

Djamarah, Syaiful Bahri dan Aswan Zain. 2010. Strategi Belajar Mengajar. Jakarta: Rineka Cipta.

Permendikbud Republik Indonesia Nomor 69 (2013). Tentang Kerangka Dasar dan Struktur Kurikulum Sekolah Menengah Atas/Madrasah Aliyah.

Sudjana 2010. Dasar-dasar Proses Belajar, Sinar Baru Bandung

Syaiful Bahri dan Aswan Zain. 2010. Strategi Belajar Mengajar. Jakarta: Rineka Cipta.

Sugiyono.2006. Metode Penelitian Kuantitatif, Kualitatif dan R \& D.Bandung:Alfabeta.

Sugiyono. 2010. Metode Penelitian Pendidikan Pendekatan Kuantitatif, kualitatif, dan R\&D. Bandung: Alfabeta

Sugiyono, 2009, Metode Penelitian Kuantitatif, Kualitatifdan R\&D, Bandung : Alfabeta. 